\title{
Assessment of heterosis and inbreeding depression for grain yield and contributing traits in bread wheat
}

\author{
Satnam Singh Nagar ${ }^{1}$, Pradeep Kumar ${ }^{2}$, Charan Singh², Vikas Gupta ${ }^{2}$, Gyanendra Singh ${ }^{2}$ and Bhudev \\ Singh Tyagi ${ }^{2}$
}

${ }^{1}$ Narendra Deva University of Agriculture and Technology, Faizabad, Uttar Pradesh, India

${ }^{2}$ ICAR-Indian Institute of Wheat and Barley Research, Karnal, Haryana, India

\section{Article history}

Received: 09 May,2019

Revised : 06 Aug., 2019

Accepted: 08 Aug., 2019

\section{Citation}

Nagar SS, P Kumar, C Singh, V Gupta, G Singh and BS Tyagi 2019. Assessment of heterosis and inbreeding depression for grain yield and contributing traits in bread wheat. Journal of Cereal Research 11(2): 125-130 doi.org/ 10.25174/2249-4065/2019/89648

\section{"Corresponding author}

Email: pradeeptaliyan231@gmail.com,

(C) Society for Advancement of Wheat and Barley Research

\section{Introduction}

Wheat is one of the most important staple food of about $36 \%$ of the world populations (Arya et al., 2018). Therefore, the yield of wheat needs to be increased up to $70-110 \%$ globally by 2050 (Tilman et al., 2011). The food security is one of prime importance for any country and is often defined in terms of food production/availability, food access and food

\begin{abstract}
A study was conducted for the assessment of heterosis and inbreeding depression for grain yield and its contributing traits in bread wheat using a $13 \times 13$ diallel fashion excluding reciprocals. The analyses of heterosis over mid parent (MP), better parent (BP) as well as the standard check (SC; NW 1014) were carried out in $78 F_{1}$ and $F_{2}$ crosses and inbreeding depression in $\mathbf{F}_{2}$ crosses. Biological yield exhibited maximum degree of SC, BP and MP heterosis $(46.96 \%, 39.98 \%$ and $31.78 \%)$, followed by grain yield $(35.27 \%, 27.58 \%$ and $20.52 \%)$, respectively. The crosses viz., PBW $343 \times$ HI 1563 for plant hight $(\mathbf{P H})$, effective tillers (ET), 1000 grain weight (TGW), biological yield (BY); PBW $343 \times$ K 8962 (PH, ET, spikelets per spike (SPS), grain number per spike (GNPS), TGW, BY); RAJ $3765 \times$ UP 2490 (PH, spike lenght (SL), SPS, GNPS, TGW, BY); UP $2490 \times$ CBW 38 (SL, ET, SPS, GNPS, TGW, BY) and NW $2036 \times$ UP 2490 (SPS, GNPS, TGW, BY) expressed significant standard heterosis $(>50 \%)$ for grain yield and some other yield components. All these crosses had significant performance in both generations $\left(F_{1}\right.$ and $\left.F_{2}\right)$ hence, can be exploited for the development of high yielding lines and/or isolation of desirable transgressive segregants. Thus these crosses combinations may be used for developing superior genotypes. The crosses viz, PBW $343 \times \mathrm{RAJ}$ 3765 (-26.17), RAJ $3765 \times$ HP $1744(-20.66)$, NW $1014 \times$ CBW 38 (-19.95), RAJ $3765 \times$ CBW 38 (-10.31), HP $1744 \times$ CBW 38 (-9.71) and UP $2425 \times$ CBW $38(-5.87)$ express negative significant inbreeding depression for grain yield and also exhibited $>15 \%$ heterosis over three parents, indicating non-additive type of gene action in the inheritance of these characters and therefore these crosses could be used for further improvement of grain yield in bread wheat.
\end{abstract}

Keywords: Bread wheat, diallel analysis, grain yield, heterosis, inbreeding depression

utilization. To meet this future food demand, we should have solutions for rigid challenges such as climate change with increased population in the world including India. Further, the success of any breeding strategy depends on the presence of genetic variability in the breeding materials, proper selection of parents, mating system employed and the breeder's keen judgment in selecting superior genotypes within the 
segregating populations. The simultaneous studies of heterosis and inbreeding depression estimates give an idea about gene action involved in the expression of various quantitative traits and help in devising breeding methodology for further improvement (Deshpandey and Nayeem, 1999). Knowledge on the expression levels of heterosis and inbreeding depression are useful to help breeders to choose the best hybrid combinations which will serve as the basis for the selection of superior genotypes. The estimates of heterosis in crop species can be determined in terms of increases in growth rate, total biomass, stress resistances, seed yield, and population fitness (Kalloo et al., 2006). Wheat is an important cereal crop and expresses 10-25 \% of heterosis (Hoisington et al., 1999). The estimates of heterosis over standard check for grain yield ranged from 6 per cent (Borghi et al., 1986) to as high as 41 per cent (Yadav and Murty, 1976). Self-pollination of hybrids over several generations leads to a gradual reduction in heterozygosity as well as vigour is known as inbreeding depression. Therefore, both heterosis and inbreeding depression are two different aspect of crop improvement (Zirkle, 1952). The magnitude of heterosis helps in determining genetic diversity and serves as a guide in the selection of desirable parents. The superiority of hybrids particularly over high parent is more useful for commercial exploitation of heterosis and also parental combinations capable of producing the highest level of transgressive segregants (Singh et al., 2004). Whereas inbreeding is essential for providing the base material for selection because it produced better segregants in wheat (Gaur, 2014). Therefore, the present study was carried out to assess the magnitude of heterosis and inbreeding depression in bread wheat and to identify superior crosses which would be gainfully utilize in future wheat improvement programmes.

\section{Materials and methods}

The primary breeding material comprised of 13 released varieties (NW 1014, NW 2036, PBW 502, PBW 343, K 8962, HI 1563, DBW 14, RAJ 3765, RAJ 4120, HP 1744, UP 2490, UP 2425 and CBW 38) of bread wheat. All the 13 released varieties used as parents were planted at main experiment station of Narendra Deva University of Agriculture and Technology, Kumarganj, Faizabad (U.P.) during rabi 2012-2013 for attempting the crosses in a $13 \times 13$ diallel mating design excluding reciprocals. During off-season in the year of 2013, $F_{1}$ seed of 78 crosses were raised at IARI Regional Research Station, Wellington, Tamil Nadu for generation advancement. In the successive crop season during rabi 2013-2014, the experimental materials comprised of 13 parents along with their 78 $\mathrm{F}_{1 \mathrm{~s}}$ and $78 \mathrm{~F}_{2 \mathrm{~s}}$ were evaluated in a randomized block design (RBD) with three replications. Each genotype was planted in a single row plot of $3 \mathrm{~m}$ length with a spacing of $23 \mathrm{~cm}$ and $10 \mathrm{~cm}$ between rows and between plants respectively with advocated agronomic practices to raise a good crop. The observations were recorded on five (05) randomly selected plants in parents, 10 plants in $\mathrm{F}_{1}$ generation and 20 plants in $\mathrm{F}_{2}$ generation for days to $50 \%$ flowering, days to maturity, plant height $(\mathrm{cm})$, spike length $(\mathrm{cm})$, number of effective tillers per plant, number of spikelets per spike, number of grains per spike, 1000-grain weight (g), biological yield per plant $(\mathrm{g})$ and grain yield per plant $(\mathrm{g})$. The diallel cross analysis was carried out by the method as described by Mather and Jinks (1982). The estimates of heterosis and inbreeding depression were computed as per standard procedures (Fonseca and Patterson, 1968). In the present study we calculated three type of heterosis. 1). Mid-parent heterosis $(\%)=\left(\mathrm{F}_{1}-\mathrm{MP}\right) / \mathrm{MP} \times 100$, where $\mathrm{F}_{1}=$ Mean performance of $\mathrm{F}_{1}$ hybrid; $\mathrm{MP}=$ Mean performance of mid-parent. 2). Better parent heterosis $(\%)=\left(\mathrm{F}_{1}-\mathrm{BP}\right) / \mathrm{BP} \times 100$, where $\mathrm{F}_{1}=$ Mean performance of $\mathrm{F}_{1}$ hybrid; $\mathrm{BP}=$ Mean performance of better parent. 3). Standard check heterosis $(\%)=\left(\mathrm{F}_{1}-\mathrm{SC}\right) / \mathrm{SC} \times 100$, where $\mathrm{F}_{1}=$ Mean performance of $\mathrm{F}_{1}$ hybrid; $\mathrm{SC}=$ Mean performance of standard check. A widely adopted and released variety (NW 1014) was considered as standard check for the estimation of standard heterosis in $F_{1}$ generation for various yield components studied. In the present study, the estimation of heterosis was measured as the superiority of $F_{1}$ cross combination over their respective standard, better as well as mid-parent values for the estimation of standard, better and midparent heterosis respectively, for grain yield and yield components. Inbreeding depression was calculated when both $F_{1}$ and $F_{2}$ population of the same cross were available and measure as inbreeding depression $(\%)=$ $\left(\mathrm{F}_{1}-\mathrm{F}_{2}\right) / \mathrm{F}_{1} \times 100$, where $\mathrm{F}_{1}=$ Mean performance of $\mathrm{F}_{1}$ hybrid; $\mathrm{F}_{2}=$ Mean performance of $\mathrm{F}_{2}$ hybrid.

\section{Results and discussion}

The heterosis is desirable for wheat crop in respect to various yield traits either in the negative or positive direction. There are some cross combinations which showed desirable heterosis for more than one trait, and some crosses showed desirable heterosis for only one trait. A wide variation of heterosis range, heterosis means and numbers of desirable hybrids were found for most of the traits over three parents (standard, better and mid-parents) under study (Table 1). In the present study, standard, better and mid parent heterosis ranged from - 16.59 to $90.26,-29.15$ to 77.94 and -24.85 to 60.53 with a mean value of $35.27,27.58$ and 20.52 , respectively for grain yield per plant. The estimates of heterosis indicating, that biological yield per plant exhibited the highest degree of standard heterosis, better parent heterosis and average heterosis $(46.96 \%$, 
Assessment of heterosis and inbreeding depression for grain yield and contributing traits in bread wheat.

$39.98 \%$ and $31.78 \%$ ), followed by grain yield per plant $(35.27 \%, 27.58 \%$ and $20.52 \%)$ respectively. However, the magnitude and direction of heterosis varied for cross to cross and trait to trait in 78 cross combinations. Some other yield contributing traits which showed significant and desirable heterosis over all three parents were 1000 -grain weight $(2.80 \%, 1.41 \%$ and $5.61 \%)$, number of grains per spike $(3.83 \%, 0.74 \%$ and $2.05 \%)$, number of spikelets per spike $(5.29 \%, 1.33 \%$ and $13.28 \%)$ and plant height $(-2.53 \%,-8.19 \%$ and $-4.86 \%)$.
The results also indicated that the traits, viz, plant height (negative heterosis), more number of grains per spike, more number of spikelets per spike, 1000-grain weight, high biological yield per plant and high grain yield per plant (positive heterosis) had all three types of heterosis. The manifestation of significant and desirable heterosis for grain yield, 1000-grain weight, biological yield, plant height and number of grains per spike was also reported by Singh et al. (2013) and Kumar et al. (2015). Similarly, significant and desirable heterosis for

Table 1. Estimation of heterosis (standard, better and mid-parent), and inbreeding depression in diallel crosses of bread wheat for grain yield and yield components

\begin{tabular}{|c|c|c|c|c|}
\hline Trait & Type of heterosis & Heterosis range & Heterosis mean & No. of desirable crosses $\left(\mathrm{F}_{1}\right)$ \\
\hline \multirow{4}{*}{ Days to $50 \%$ flowering } & Mid parent & $(-5.00)-(8.07)$ & 1.10 & 13 \\
\hline & Better parent & $(-8.12)-(4.17)$ & -0.73 & 17 \\
\hline & Standard check & $(-3.70)-(12.50)$ & 2.40 & 3 \\
\hline & Inbreeding depression & $(-4.74)-(4.51)$ & 0.06 & 7 \\
\hline \multirow{4}{*}{ Days to maturity } & Mid parent & $(-2.75)-(3.03)$ & -0.32 & 21 \\
\hline & Better parent & $(-4.08)-(1.93)$ & -0.91 & 34 \\
\hline & Standard check & $(-1.67)-(4.18)$ & 1.05 & 2 \\
\hline & Inbreeding depression & $(-1.11)-(2.19)$ & 0.19 & - \\
\hline \multirow{4}{*}{ Plant height } & Mid parent & $(-20.90)-(17.76)$ & -2.53 & 34 \\
\hline & Better parent & $(-33.87)-(5.13)$ & -8.19 & 43 \\
\hline & Standard check & $(-22.75)-(22.01)$ & -4.86 & 37 \\
\hline & Inbreeding depression & $(-3.08)-(2.74)$ & 0.32 & 2 \\
\hline \multirow{4}{*}{ Spike length } & Mid parent & $(18.99)-(13.11)$ & -0.18 & 74 \\
\hline & Better parent & $(-30.35)-(7.55)$ & -5.42 & 7 \\
\hline & Standard check & $(-16.32)-(25.00)$ & -2.56 & 14 \\
\hline & Inbreeding depression & $(-3.86)-(5.88)$ & 0.57 & 3 \\
\hline \multirow{4}{*}{$\begin{array}{l}\text { Number of effective tiller } \\
\text { per plant }\end{array}$} & Mid parent & $(-22.22)-(36.81)$ & 7.45 & 42 \\
\hline & Better parent & $(29.41)-(22.41)$ & 0.05 & 26 \\
\hline & Standard check & $(-30.46)-(25.86)$ & -7.52 & 14 \\
\hline & Inbreeding depression & $(-66.23)-(27.75)$ & -1.56 & 7 \\
\hline \multirow{4}{*}{$\begin{array}{l}\text { Number of spikelets per } \\
\text { spike }\end{array}$} & Mid parent & $(-15.60)-(19.27)$ & 5.29 & 8 \\
\hline & Better parent & $(-23.33-14.58)$ & 1.33 & 8 \\
\hline & Standard check & $(-8.51)-(38.30)$ & 13.28 & 46 \\
\hline & Inbreeding depression & $(-7.41)-(15.69)$ & 1.48 & - \\
\hline \multirow{4}{*}{ Number of grains per spike } & Mid parent & $(-24.46)-(35.18)$ & 3.83 & 14 \\
\hline & Better parent & $(-33.10)-(31.54)$ & 0.74 & 31 \\
\hline & Standard check & $(-29.10)-(28.36)$ & 2.05 & 36 \\
\hline & Inbreeding depression & $(-29.52)-(15.97)$ & -3.46 & 31 \\
\hline \multirow{4}{*}{ 1000-grain weight } & Mid parent & $(-17.67)-(15.84)$ & 2.80 & 43 \\
\hline & Better parent & $(-20.48)-(15.19)$ & 1.48 & 33 \\
\hline & Standard check & $(-15.05)-(18.23)$ & 5.61 & 35 \\
\hline & Inbreeding depression & $(-17.31)-(18.39)$ & 0.45 & 15 \\
\hline \multirow{4}{*}{ Biological yield per plant } & Mid parent & $(-7.89)-(93.72)$ & 46.66 & 71 \\
\hline & Better parent & $(-17.59)-(119.71)$ & 39.98 & 62 \\
\hline & Standard check & $(-16.63)-(73.92)$ & 31.78 & 62 \\
\hline & Inbreeding depression & $(-45.28)-(40.99)$ & 4.24 & 12 \\
\hline \multirow{4}{*}{ Grain yield per plant } & Mid parent & $(-16.59)-(90.26)$ & 35.27 & 63 \\
\hline & Better parent & $(-29.15)-(77.94)$ & 27.58 & 60 \\
\hline & Standard check & $(-24.85)-(60.53)$ & 20.52 & 55 \\
\hline & Inbreeding depression & $(-26.17)-(29.85)$ & 0.48 & 9 \\
\hline
\end{tabular}


number of grains per spike, number of spikelets per spike, 1000-grain weight, biological yield per plant and grain yield per plant by Kumar et al. (2017) in wheat. The presence of high heterosis for grain yield and its contributing traits is not only for developing hybrids but also helps to produce transgressive segregants for developing of superior homozygous lines.

At the time of plant selection, grain yield received maximum attention of plant breeder in any plant breeding programme. Therefore, highest positive and significant heterosis for grain yield is desirable. The top 10 crosses were selected out of 78 crosses, which expressed highest significant positive heterosis over all three parents (standard, better and mid-parent) for grain yield along with its contributing traits (Table 2). The cross combination PBW $343 \times$ HI 1563 expressed heterosis for four traits (biological yield per plant, 1000-grain weight, number of effective tillers per plant and plant height). Similarly the crosses, PBW $343 \times \mathrm{K}$ 8962, RAJ $3765 \times$ UP 2490 , UP $2490 \times$ CBW 38, NW $2036 \times$ UP 2490, NW $1014 \times$ UP 2490, DBW $14 \times$ UP 2490, DBW $14 \times$ RAJ 4120, DBW $14 \times$ CBW 38 and NW $1014 \times$ RAJ 4120 exhibited heterosis for different yield contributing traits (Table 3 ). The significant and desirable heterosis was also reported by (Singh et al. 2013) for grain yield; (Kumar et al. 2015) for grain yield, 1000-grain weight, biological yield, plant height and number of grains per spike. Similarly, for number of grains per spike, number of spikelets per spike, 1000 -grain weight, biological yield per plant and grain yield per plant by Kumar et al. (2017) in wheat.

In the present investigation, none of the crosses showed significant heterosis for all the yield components studied over standard, better as well as mid-parent. The results also indicated that that the degree and direction of heterosis varied not only from character to character but also among cross combinations. Heterosis may be high or low depending upon the mean value of the respective parent. Obviously, there may be a possibility of getting a cross with high mean performance but with low heterosis, in case the parental performance is also high. In contrast, there may be a cross with poor mean performance but high heterosis. It means that the choice of the best cross combination on the basis of high heterosis would not necessarily be one which would give the high mean performance. The mean performance being the realized value, and the heterotic response being an estimate, the formers would be given preference with high percentage of heterosis while making selection of cross combination.

More desirable crosses showed negative and significant inbreeding depression for various yield components (Table 3). The direction and magnitude of inbreeding depression varied from cross to cross for all the yield component traits. Out of 78 crosses, top nine crosses were selected which showed the highest negative and significant inbreeding depression for grain yield per plant as well as for other component traits. The range of inbreeding depression for grain yield was (-26.17 $29.85)$, days to $50 \%$ flowering $(-4.74)-(4.51)$, days to maturity $(-1.11)-(2.19)$, plant height $(-3.08)-(2.74)$ and spike length (-3.86) - (5.88). Similarly, the range of inbreeding depression for number of effective tillers per plant, number of spikelets per spike, number of grains per spike, 1000-grain weight and biological yield per plant is given in Table 1 .

Table 2. Estimation of standard heterosis for grain yield and yield components based on promising top 10 single crosses of bread wheat in $\mathrm{F}_{1}$ and $\mathrm{F}_{2}$ generation

\begin{tabular}{|c|c|c|c|c|c|c|c|}
\hline \multirow[t]{2}{*}{ Crosses } & \multicolumn{2}{|c|}{ Standard check } & \multicolumn{2}{|c|}{ Better parent } & \multicolumn{2}{|c|}{ Mid-parent } & \multirow{2}{*}{$\begin{array}{l}\text { Significant standard heterosis } \\
\text { for other yield components }\end{array}$} \\
\hline & $\mathrm{F}_{1}$ & $\mathrm{~F}_{2}$ & $\mathrm{~F}_{1}$ & $\mathrm{~F}_{2}$ & $\mathrm{~F}_{1}$ & $\mathrm{~F}_{2}$ & \\
\hline PBW 343 × HI 1563 & $60.53^{* *}$ & $54.09^{* *}$ & $75.96^{* *}$ & $68.91^{* *}$ & $80.30^{* *}$ & $73.07^{* *}$ & PH, ET, TGW, BY \\
\hline PBW $343 \times$ K 8962 & $59.94^{* *}$ & $46.49^{* *}$ & $75.32^{* *}$ & $60.58^{* *}$ & $90.26^{* *}$ & $74.26^{* *}$ & PH, ET, SPS, GNPS, TGW, BY \\
\hline RAJ $3765 \times$ UP 2490 & $58.77^{* *}$ & $47.66^{* *}$ & $61.13^{* *}$ & $49.85^{* *}$ & $62.09^{* *}$ & $50.75^{* *}$ & PH, SL, SPS, GNPS, TGW, BY \\
\hline UP $2490 \times$ CBW 38 & $55.85^{* *}$ & $50.29^{* *}$ & $58.16^{* *}$ & $52.52^{* *}$ & $80.68^{* *}$ & $74.24^{* *}$ & SL, ET, SPS, GNPS, TGW, BY \\
\hline NW $2036 \times$ UP 2490 & $52.63^{* *}$ & $21.93^{* *}$ & $54.90^{* *}$ & $23.74^{* *}$ & $71.99^{* *}$ & $37.40^{* *}$ & SPS, GNPS, TGW, BY \\
\hline NW $1014 \times$ UP 2490 & $49.42^{* *}$ & $32.16^{* *}$ & $49.42^{* *}$ & $32.16^{* *}$ & $50.52^{* *}$ & $33.14^{* *}$ & ET, SPS, GNPS, TGW, BY \\
\hline DBW $14 \times$ UP 2490 & $49.12 * *$ & $48.25^{* *}$ & $51.34^{* *}$ & $50.45^{* *}$ & $53.38^{* *}$ & $52.48^{* *}$ & PH, SPS, GNPS, TGW, BY \\
\hline DBW $14 \times$ RAJ 4120 & $48.83^{* *}$ & $39.47^{* *}$ & $55.18^{* *}$ & $45.43^{* *}$ & $61.33^{* *}$ & $51.19^{* *}$ & DTF, PH, SPS, GNPS, TGW, BY \\
\hline DBW $14 \times$ CBW 38 & $46.49^{* *}$ & $47.08^{* *}$ & $52.74^{* *}$ & $53.35^{* *}$ & $72.46^{* *}$ & $73.15^{* *}$ & PH, SPS, TGW, BY \\
\hline NW $1014 \times$ RAJ 4120 & $46.20^{* *}$ & $44.15^{* *}$ & $46.20^{* *}$ & $44.15^{* *}$ & $55.04^{* *}$ & $52.87^{* *}$ & SL, ET, SPS, TGW, BY \\
\hline
\end{tabular}

* Significant at 5\% level, ** significant at 1\% level, Days to $50 \%$ flowering (DTF), Days to maturity (DTM), Plant height (PH), Spike length (SL), Number of effective tillers per plant (ET), Number of spikelets per spike (SPS), Grains number per spike (GNPS), 1000-grain weight (TGW), Biological yield per plant (BY), and Grain yield per plant (GY) 
A wide range of inbreeding depression for grain yield per plant, days to $50 \%$ flowering, plant height, number of effective tillers per plant, 1000-grain weight, number of spikelets per spike, number of grains per spike and biological yield per plant was also reported (Jaiswal $e t$ al. 2018). Similarly, Kumar et al. (2017) reported a wide range of inbreeding depression for number of effective tillers per plant, 1000-grain weight, number of spikelets per spike, number of grains per spike, spike length and grain yield per plant in wheat.

The heterotic expression normally declines in $\mathrm{F}_{2}$ generation as the dominance effect dissipates in $\mathrm{F}_{2}$ generation due to reduced heterozygosity, thereby resulting into inbreeding depression. The negative and significant inbreeding depression was observed for various yield traits studied but in the present study nine crosses exhibited negative and significant inbreeding depression for grain yield. Out of these nine crosses, six showed negative and significant inbreeding depression along with positive and significant heterosis over all three parents for grain yield. The cross PBW $343 \times$ RAJ 3765 (-26.17) expressed negative and significant inbreeding depression for grain yield along with number of grains per spike. Similarly, the crosses RAJ $3765 \times$ HP 1744, NW $1014 \times$ CBW 38, RAJ $3765 \times$ CBW 38, HP $1744 \times$ CBW 38, and UP $2425 \times$ CBW 38 expressed negative and significant inbreeding depression for grain yield and these crosses also have $>15 \%$ heterosis over all three parents. Therefore, the above-selected cross combinations may be utilized for improving grain yield as well as for the identification/ selection of transgressive segregants. Kumar et al. (2017) observed that $F_{2}$ progenies performance for inbreeding depression might be a good indicator of predicting heterosis performance in $\mathrm{F}_{1}$ hybrid of wheat. The negative and significant inbreeding depression indicating that the concerned trait controlled by additive gene action and could be improving though subsequent selection scheme of plant breeding. The crosses which showed high heterosis followed by inbreeding depression indicate the presence of nonadditive type of gene action and vice-versa. The above selected crosses exhibited negative and significant inbreeding depression for grain yield and other yield components which can be used to maintain the specific gene pool for further utilization in wheat improvement.

In light of the above findings, it may be concluded that all the crosses exhibited heterosis in one or more traits. But in general, biological yield exhibited highest amount of standard, better and mid-parent heterosis $(46.96 \%, 39.98 \%$ and $31.78 \%)$, followed by grain yield $(35.27 \%, 27.58 \%$ and $20.52 \%)$ respectively. The top five selected crosses (PBW $343 \times$ HI 1563, PBW $343 \times \mathrm{K}$ 8962, RAJ $3765 \times$ UP 2490, UP $2490 \times$ CBW 38 and NW $2036 \times$ UP 2490) expressed highest significant and positive heterosis over standard check $(>50 \%)$ for grain yield along with some other yield contributing traits, which can be used to select transgressive segregants. The cross PBW $343 \times$ RAJ 3765, RAJ $3765 \times$ HP 1744, NW $1014 \times$ CBW 38, RAJ $3765 \times$ CBW 38, HP $1744 \times$ CBW 38 and UP $2425 \times$ CBW 38 expressed negative and significant inbreeding depression for grain yield and these crosses also have $>15 \%$ heterosis over all three parents, therefore these crosses could be used for improvement in bread wheat. Inbreeding depression based on genetic variability indicated the positive and negative expression of genes in the population which could not be fixed for heterosis breeding. The positive and negative expressions indicated the role of dominant and recessive genes in the inheritance of the characters. The cross combinations which showed high heterosis followed by inbreeding depression indicating the presence of non-additive type of gene action and vice-versa. Therefore, in the present study,

Table 3. Estimation of inbreeding depression and heterosis (standard, better and mid-parent) for grain yield and yield components based on promising crosses of bread wheat in $\mathrm{F}_{2}$ generation

\begin{tabular}{|c|c|c|c|c|c|}
\hline Crosses & $\begin{array}{l}\text { Inbreeding } \\
\text { depression }\end{array}$ & $\begin{array}{l}\text { Standard } \\
\text { check }\end{array}$ & $\begin{array}{l}\text { Better } \\
\text { parent }\end{array}$ & $\begin{array}{c}\text { Mid } \\
\text { parent }\end{array}$ & $\begin{array}{c}\text { Significant inbreeding depression for other } \\
\text { yield components }\end{array}$ \\
\hline PBW $343 \times$ RAJ 3765 & $-26.17^{* *}$ & $59.94^{* *}$ & $75.32^{* *}$ & $90.26^{* *}$ & Grains number per spike \\
\hline RAJ $3765 \times$ HP 1744 & $-20.66^{* *}$ & $16.08^{* *}$ & $19.22^{* *}$ & $31.24^{* *}$ & Grains number per spike, 1000-grain weight \\
\hline K $8962 \times$ RAJ 4120 & $-21.68^{* *}$ & $-9.65^{*}$ & 1.98 & $9.19^{*}$ & Grains number per spike \\
\hline NW $1014 \times$ CBW 38 & $-19.95^{* *}$ & $21.64^{* *}$ & $21.64^{* *}$ & $39.83^{* *}$ & Days to $50 \%$ flowering, 1000 -grain weight \\
\hline HI $1563 \times$ UP 2425 & $-12.27^{*}$ & $-21.35^{* *}$ & $-22.70^{* *}$ & $-16.59^{* *}$ & Grains number per spike \\
\hline RAJ $3765 \times$ CBW 38 & $-10.31^{*}$ & $21.93^{* *}$ & $25.23^{* *}$ & $42.32 * *$ & 1000-grain weight \\
\hline PBW $343 \times$ DBW 14 & $-11.71^{* *}$ & $-7.89^{*}$ & -6.53 & -2.93 & Grains number per spike \\
\hline HP $1744 \times$ CBW 38 & $-9.71^{*}$ & $41.52^{* *}$ & $77.94^{* *}$ & $84.38^{* *}$ & 1000-grain weight \\
\hline UP $2425 \times$ CBW 38 & $-5.87^{*}$ & $55.85^{* *}$ & $70.76^{*}$ & $24.79^{* *}$ & - \\
\hline
\end{tabular}

* Significant at $5 \%$ level, ${ }^{* *}$ significant at $1 \%$ level 
it is suggested that the selected crosses should be used for further improvement in the wheat crop through the traits of interest to the breeder.

\section{References}

1. Arya VK, P Kumar, J Singh, L Kumar and AK Sharma. 2018. Genetic analysis of some yield and quality traits in bread wheat (Triticum aestivum L.). Wheat and Barley Research 10(1): 25-32.

2. Borghi B, M Corbellini, MM Cattaneo, E Fornasari and L Zucchelli. 1986. Modification of the sink/source relationships in bread wheat and its influence on grain yield and grain protein. Agronomy Journal 157:245-254.

3. Deshpandey DP and KA Nayeem. 1999. Heterosis for heat tolerance, protein content, yield and yield components in bread wheat (Triticuma estivum L.). Indian Journal of Genetics and Plant Breeding 59(1): 13-22.

4. Fonseca S and FL Patterson. 1968. Hybrid vigour in a seven parent diallel cross in common wheat (T. aestivum). Crop Science 8:85-90.

5. Gaur SC, SN Singh, LP Tiwari and LB Gaur. 2014. Heterosis and inbreeding depression in the inheritance of grain yield and it's components in wheat (Triticum aestivum). Current Advances in Agricultural Sciences 6(2): 186-189.

6. Hoisington D, M Khairallah, T Reeves, JM Ribaut, B Skovmand, S Taba and M Warburton. 1999. Plant genetic resources: what can they contribute toward increased crop productivity? Proceeding of National Academy and Science USA 96(11): 5937-5943.

7. Jaiswal R, SC Gaur and SK Jaiswal.2018. Heterosis and inbreeding depression for grain yield and yield component traits in bread wheat (Triticuma estivum L.). Journal of Pharmacognosy and Phytochemistry 7(2): 3586-3594
8. Kalloo G, M Rai, M Singh and S Kumar. 2006. Heterosis in crop plants. Research co Book Centre, New Delhi.

9. Kumar Pradeep, Gyanendra Singh, YP Singh and Sarvan Kumar. 2015. Identification of best heterotic cross combination from diallel crosses for grain yield and other agro-morphological traits in bread wheat (Triticuma estivum L.). Electronic Journal of Plant Breeding 6(4): 938-949.

10. Kumar Sandeep, Pradeep Kumar, V K Arya, Ravi Kumar, Gaurav Kamboj and SA Kerkhi. 2017. Identification of heterotic cross combinations for various agromorphological and some quality traits in bread wheat (Triticuma estivum L.). Journal of Applied and Natural Science 9(4): 2013-2020.

11. Mather K and JL Jinks. 1982. Biometrical Genetics: The Study of Continuous Variation. Chapman and Hall Inc., London.

12. Singh H, SN Sharma and RS Sain. 2004. Heterosis studies for yield and its components in bread wheat over environments. Hereditas 141: 106-14.

13. Singh MK, PK Sharma, BS Tyagi and G Singh. 2013. Heterosis for yield component traits and protein content in bread wheat under normal and heat-stress environment. Cereal Research Communications 42(1):151-162.

14. Tilman D, C Balzer, J Hill and BL Befort. 2011. Global food demand and the sustainable intensification of agriculture. Proceeding of National Academy and Science 108(50): 20260-20264.

15. Yadav SP and BR Murty. 1976. Heterosis and combining ability in crosses of different height categories in bread wheat. Indian Journal of Genetics and Plant Breeding 36: 184-196.

16. Zirkle C. 1952. Early ideas on inbreeding and cross breeding. In Heterosis (Gowen, J.W., ed.), pp. 1-13, Iowa State College Press. 